\title{
16S rDNA-based analysis reveals cosmopolitan occurrence but limited diversity of two cyanobacterial lineages with contrasted patterns of intracellular carbonate mineralization
}

\author{
Marie Ragon 1,2, Karim Benzerara ${ }^{1}$, David Moreira ${ }^{2}$, Rosaluz Tavera ${ }^{3}$ and Purificación López-García ${ }^{2 *}$ \\ ${ }^{1}$ Institut de Minéralogie, de Physique des Matériaux, et de Cosmochimie, Sorbonne Universités - UPMC Univ Paris 06, CNRS UMR 7590, MNHN, IRD UMR 206, \\ Paris, France \\ 2 Unité d'Ecologie, Systématique et Evolution, Centre National de la Recherche Scientifique CNRS UMR8079, Université Paris-Sud, Orsay, France \\ ${ }^{3}$ Departamento de Ecología y Recursos Naturales, Universidad Nacional Autónoma de México, DF Mexico, Mexico
}

\section{Edited by:}

George S. Bullerjahn, Bowling Green

State University, USA

Reviewed by:

Martin W. Hahn, University of

Innsbruck, Austria

Boglárka Somogyi, Balaton

Limnological Institute, Hungary

*Correspondence:

Purificación López-García, Unité d'Ecologie, Systématique et

Evolution, Centre National de la Recherche Scientifique CNRS UMR8079, Université Paris-Sud, Batiment 360, 91405 Orsay, France e-mail:puri.lopez@u-psud.fr
Cyanobacteria are mainly thought to induce carbonate precipitation extracellularly via their photosynthetic activity combined with the nucleation potential of exopolymeric substances. The discovery in microbialites of the alkaline lake Alchichica (Mexico) of Candidatus Gloeomargarita lithophora, a cyanobacterium forming large amounts of intracellular Mg-Ca-Sr-Ba carbonate spherules, showed that intracellular biomineralization in cyanobacteria is also possible. A second cyanobacterium isolated from the same environment, Candidatus Synechococcus calcipolaris G9, has been recently shown to also form intracellular calcium carbonates at the cell poles, a capability shared by all cultured species of the Thermosynechococcus clade, to which it belongs. To explore the diversity of these two distant cyanobacterial lineages representing two different patterns of intracellular calcification, we designed specific primers against their 16S rRNA genes and looked for their occurrence in a wide variety of samples. We identified the presence of members of the Gloeomargarita and Thermosynechococcus/S. calcipolaris lineages in microbialites collected from Lake Alchichica and three other neighboring Mexican lakes. The two clades also occurred in karstic areas and in some thermophilic or hypersaline microbial mats collected in South America and/or Southern Europe. Surprisingly, the within-group diversity in the two clades was low, especially within the S. calcipolaris clade, with all $16 \mathrm{~S}$ rRNA gene sequences retrieved sharing more than $97 \%$ identity. This suggests that these clades are composed of a limited number of operational taxonomic units (OTUs) with cosmopolitan distribution. Moreover, scanning electron microscopy coupled with energy dispersive $x$-ray spectrometry showed the presence of intracellularly calcifying Gloeomargarita-like cyanobacteria in fresh samples where this clade was relatively abundant, suggesting that these cyanobacteria do precipitate carbonates intracellularly under natural conditions.

Keywords: Gloeomargarita, Thermosynechococcus, biomineralization, microbial mat, stromatolite, thermophilic

\section{INTRODUCTION}

The formation of minerals as a consequence of microbial activity is a common phenomenon. Whereas biomineralization seems a tightly controlled process in many unicellular eukaryotes, such as haptophytes (coccolithophorids), radiolarians or diatoms (Bauerlein, 2003), prokaryotes seem to predominantly induce mineral formation indirectly. In this case, mineral precipitation mainly results from the alteration of the cell local chemical environment by its metabolic activities (Newman and Banfield, 2002). A paradigmatic example is carbonate formation.

Until very recently, calcium and/or magnesium carbonates were thought to form essentially extracellularly as a consequence of a variety of bacterial or archaeal metabolisms (Riding, 2000).
The oxygenic photosynthesis carried out by cyanobacteria is considered an important driver of carbonate precipitation in cyanobacteria-dominated microbial mats and modern stromatolites (Arp et al., 1999; Reid et al., 2000; Paerl et al., 2001; Dupraz and Visscher, 2005; Dupraz et al., 2009), where carbonates may precipitate in a variety of forms (Gerdes et al., 1994). Similarly, carbonate biomineralization would lead to the phenomenon of "whiting" induced by some planktonic cyanobacteria (Thompson et al., 1997). Two major factors are thought to influence carbonate formation by cyanobacteria. The first is the increase of $\mathrm{pH}$ (with the concomitant increase in the concentration of carbonates) resulting from photosynthetic carbon fixation, which affects the saturation index. This "alkalinity engine" leading to local 
carbonate super-saturation triggers precipitation when $\mathrm{Ca}^{2+}$ (or other cations) and when nucleation centers are available in the surroundings. Cation and nucleation center availability thus constitute the second major factor influencing carbonate precipitation and, in cyanobacteria, exopolymeric substances (EPS) that surround cyanobacterial cells are thought to supply them both (Dupraz et al., 2009; Obst et al., 2009). Accordingly, carbonate biomineralization by cyanobacteria has been considered exclusively as an extracellular process. In addition to cyanobacteria, other prokaryotes display metabolic activities susceptible to act as "alkalinity engines," although they appear to have a lesser impact on a global scale. They include, among others, anoxygenic photosynthetic bacteria (Bundeleva et al., 2012), sulfate reducing bacteria (Visscher et al., 2000; Gallagher et al., 2012), ureolytic bacilli (Hammes et al., 2003) and other Gram positive desert bacteria (Rivadeneyra et al., 1999), myxobacteria (RodriguezNavarro et al., 2003) or anaerobic methane oxidizers (Michaelis et al., 2002).

Photosynthesis-induced calcification has been active since early evolutionary times, leaving macroscopic (stromatolite), and other type of traces in the fossil record (Arp et al., 2001; Riding, 2006). This calcification was thought to be extracellular and, in this sense, the use of high-resolution techniques including electron, confocal, and x-ray microscopies has allowed the detection of particular mineral signatures at nanoscale around encrusted cells in modern microbialites (Benzerara et al., 2006) that might be preserved in older fossils. Mineral biosignatures witnessing encrustment are sometimes specifically associated to very particular cyanobacterial species in otherwise highly diversified microbialite communities (Couradeau et al., 2013; Gerard et al., 2013), which confirms previous suspicions of a strong taxonomic control on fossilization/mineralization (Planavsky et al., 2009).

Despite the recognized importance of extracellular calcification by cyanobacteria in modern and past settings, the recent discovery of one cyanobacterium, Candidatus Gloeomargarita lithophora, able to produce intracellular carbonates (Couradeau et al., 2012) opened questions about the extent of this phenomenon and its potential contribution to the ancient fossil record (Riding, 2012). The presence of intracellular mineral inclusions in some bacteria has been known for a long time. Granules of elemental sulfur are produced by several anoxygenic phototrophs (Overmann and Garcia-Pichel, 2000) and colorless sulfur bacteria (Robertson and Kuenen, 2006) and many bacteria produce polyphosphate storage inclusions including, notably, cyanobacteria (Seufferheld et al., 2003; GomezGarcia et al., 2013), and magnetotactic bacteria (Lins and Farina, 1999). Magnetite $\left(\mathrm{Fe}_{3} \mathrm{O}_{4}\right)$-producing bacteria offer the best known example of controlled biomineralization among prokaryotes (Greene and Komeili, 2012; Lefevre and Bazylinski, 2013). However, except for the poorly-studied genus Achromatium (A.oxalyphera, A.mobile = Macromonas mobilis) (Head et al., 1996), intracellular carbonate inclusions were not known. The discovery of G. lithophora, the first-known cyanobacterium producing intracellular carbonates has triggered a series of unexpected findings. Recently, a second cyanobacterium was isolated from the same sample, i.e., biofilms associated to microbialites collected from the alkaline crater lake of Alchichica, Mexico, and maintained in laboratory aquaria (Couradeau et al., 2012). This strain, tentatively named Candidatus Synechococcus calcipolaris strain G9 due to its phylogenetic affinity with some strains of the polyphyletic genus Synechococcus (Robertson et al., 2001), was found to form carbonate inclusions intracellularly as well. However, $\mathrm{Ca}$. S. calcipolaris G9 displayed a remarkable difference with $G$. lithophora, with carbonate inclusions located only at the cell poles, suggesting a potential connection with cell wall division (Benzerara et al., in press).

Candidatus Gloeomargarita lithophora and Synechococcus calcipolaris G9 thus represent two distinct mechanisms of carbonate intracellular precipitation occurring in two independent and relatively basal lineages within the Cyanobacteria. How extensive are these biomineralization processes? A partial answer comes from a recent study exploring intracellular carbonate formation across the phylogenetic diversity of cyanobacteria, which shows that this phenomenon has been overlooked in many described cyanobacterial species (Benzerara et al., in press). Also, the exploration of the diversity and abundance of these lineages in various natural environments can lead to a better estimation of their extent and ecological importance. In this work, we aimed at detecting the presence and characterizing the diversity of $G$. lithophora and $S$. calcipolaris lineages in a variety of ecosystems where carbonate precipitation may occur and/or where environmental sequences related to the two cyanobacterial strains had been previously retrieved. Our results show that the two clades are cosmopolitan, although their specific diversity seems reduced, and thrive preferentially in thermophilic microbial mats and calcareous substrates.

\section{MATERIALS AND METHODS SAMPLING, DNA PURIFICATION, PCR AMPLIFICATION, CLONING, AND SEOUENCING}

Samples analyzed in this study (Table 1) were collected during several field trips carried out by the authors in recent years or generously provided by collaborators. Samples collected abroad were fixed in ethanol in situ. Samples collected in France were either fixed or transported directly to the laboratory for immediate DNA purification. Prior to DNA extraction, subsamples of ca. $200 \mu \mathrm{l}$ volume were taken and, if applicable, ethanol was removed after a short centrifugation step (5 min, 10,000 rpm). Samples were then rehydrated in the initial resuspension buffer of the PowerBiofilm DNA isolation kit (MoBio, Carlsbad, CA USA) and the DNA purified using this kit. DNA was eluted in $100 \mu \mathrm{l}$ of Tris- $\mathrm{HCl}, \mathrm{pH} 8$, and conserved at $-20^{\circ} \mathrm{C}$. Small subunit ribosomal RNA genes were amplified by polymerase chain reaction (PCR) using primers specifically designed to target the Gloeomargarita and the Thermosynechococcus/Synechococcus clades, including some very basal sequences (colored areas in Figure 1). For the former, we designed the primers 69FGloeo (5'-AAGTCGAACGGGGKWGCAA) and 1227R-Gloeo (5'-GATCTGAACTGAGACCAAC) and for the latter, primers 209F-synG9 (5'-TGAGGATGAGCTCGCGGTG) and 1231RsynG9 (5'-GAACTGAGCCRYGGTTTAA). PCR reactions were carried out in $25 \mu \mathrm{l}$ of reaction buffer, containing $1.5 \mu \mathrm{l}$ of the eluted DNA, $1.5 \mathrm{mM} \mathrm{MgCl}_{2}$, dNTPs (10 nmol each), $20 \mathrm{pmol}$ 
Table 1 | Samples analyzed for the presence of intracellularly calcifying cyanobacterial clades.

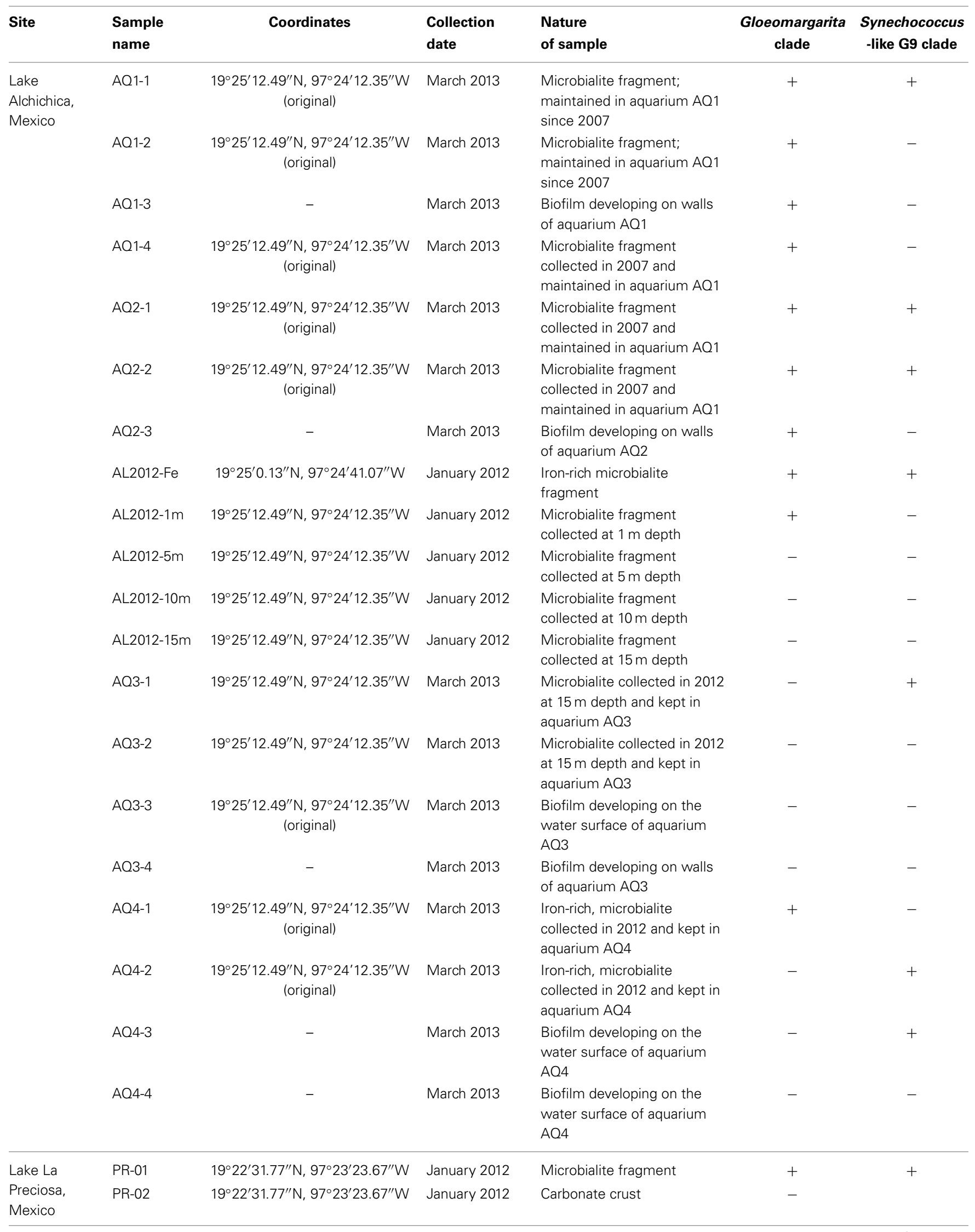


Table 1 | Continued

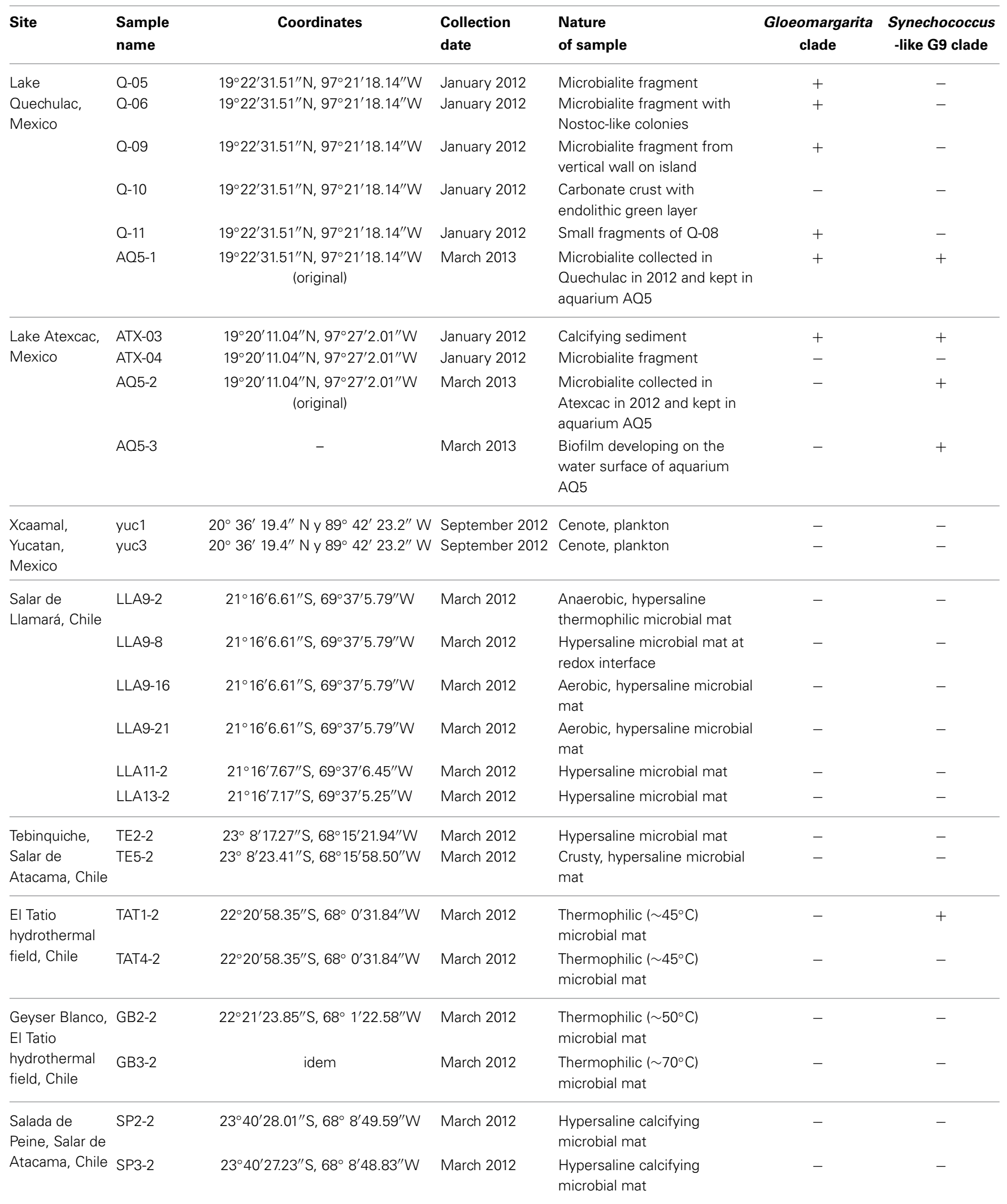




\section{Table 1 | Continued}

\begin{tabular}{|c|c|c|c|c|c|c|}
\hline Site & $\begin{array}{l}\text { Sample } \\
\text { name }\end{array}$ & Coordinates & $\begin{array}{l}\text { Collection } \\
\text { date }\end{array}$ & $\begin{array}{l}\text { Nature } \\
\text { of sample }\end{array}$ & $\begin{array}{c}\text { Gloeomargarita } \\
\text { clade }\end{array}$ & $\begin{array}{l}\text { Synechococcus } \\
\text {-like G9 clade }\end{array}$ \\
\hline $\begin{array}{l}\text { Joute River } \\
\text { valley, Parc de } \\
\text { Grands } \\
\text { Causses, } \\
\text { France }\end{array}$ & Val-Jou & $44^{\circ} 12^{\prime} 00^{\prime \prime} \mathrm{N}, 3^{\circ} 23^{\prime} 00^{\prime \prime} \mathrm{E}$ & June 2013 & Microbial mat on rock & - & - \\
\hline Meyrueis, Parc & Meyrueis1 & $44^{\circ} 11^{\prime} 06^{\prime \prime} \mathrm{N}, 3^{\circ} 26^{\prime} 18^{\prime \prime} \mathrm{E}$ & June 2013 & Microbial mat on rock & - & - \\
\hline $\begin{array}{l}\text { Lavogne de } \\
\text { Villeneuve, } \\
\text { France }\end{array}$ & Puit-Lavo & $44^{\circ} 15^{\prime} 19^{\prime \prime} \mathrm{N}, 3^{\circ} 25^{\prime} 59^{\prime \prime} \mathrm{E}$ & June 2013 & Microbial mat & + & - \\
\hline $\begin{array}{l}\text { Lavogne de } \\
\text { Villeneuve, } \\
\text { France }\end{array}$ & Lavo & $44^{\circ} 14^{\prime} 21^{\prime \prime} \mathrm{N}, 3^{\circ} 32^{\prime} 08^{\prime \prime} \mathrm{E}$ & June 2013 & Microbial mat & - & - \\
\hline $\begin{array}{l}\text { Lavogne Hure, } \\
\text { France }\end{array}$ & Lavo 0,2 & $44^{\circ} 15^{\prime} 19^{\prime \prime} \mathrm{N}, 3^{\circ} 25^{\prime} 59^{\prime \prime} \mathrm{E}$ & June 2013 & Plankton $0,2-5 \mu \mathrm{m}$ & - & - \\
\hline $\begin{array}{l}\text { Lavogne Hure, } \\
\text { France }\end{array}$ & Lavo 5 & $44^{\circ} 15^{\prime} 19^{\prime \prime} \mathrm{N}, 3^{\circ} 25^{\prime} 59^{\prime \prime} \mathrm{E}$ & June 2013 & Plankton $>5 \mu \mathrm{m}$ & - & - \\
\hline $\begin{array}{l}\text { Salada de } \\
\text { Chiprana, } \\
\text { Spain }\end{array}$ & Chip & $41^{\circ} 14^{\prime} 31.13^{\prime \prime} \mathrm{N}, 0^{\circ} 10^{\prime} 57.94^{\prime \prime} \mathrm{W}$ & March 2013 & Hypersaline microbial mat & + & - \\
\hline $\begin{array}{l}\text { Mayotte, } \\
\text { Indian Ocean, } \\
\text { France }\end{array}$ & $\begin{array}{l}\text { MAY1-2013 } \\
\text { MAY2-2013 }\end{array}$ & $\begin{array}{l}12^{\circ} 35^{\prime} 7.55^{\prime \prime} \mathrm{S}, 44^{\circ} 58^{\prime} 39.13^{\prime \prime} \mathrm{E} \\
12^{\circ} 35^{\prime} 7.55^{\prime \prime} \mathrm{S}, 44^{\circ} 58^{\prime} 39.13^{\prime \prime} \mathrm{E}\end{array}$ & $\begin{array}{l}\text { April } 2013 \\
\text { April } 2013\end{array}$ & $\begin{array}{l}\text { Microbialite biofilm } \\
\text { Hydrothermal chimney }\end{array}$ & - & $\begin{array}{l}- \\
-\end{array}$ \\
\hline
\end{tabular}

When not indicated otherwise, microbialite samples were collected near the water surface.

of each primer, and $0.2 \mathrm{U}$ Taq platinum DNA polymerase (Invitrogen). PCR reactions were performed under the following conditions: 35 cycles (denaturation at $94^{\circ} \mathrm{C}$ for $15 \mathrm{~s}$, annealing at $55^{\circ} \mathrm{C}$ for $30 \mathrm{~s}$, extension at $72^{\circ} \mathrm{C}$ for $2 \mathrm{~min}$ ) preceded by 2 min denaturation at $94^{\circ} \mathrm{C}$, and followed by $7 \mathrm{~min}$ extension at $72^{\circ} \mathrm{C}$. Negative (no DNA) and positive (DNA from available targeted cyanobacteria) controls for PCR reactions were used in all cases. DNA from G. lithophora and from $S$. calcipolaris, T. elongatus, and Synechococchus sp. strains PCC6716 and 6717 was used, respectively, as positive control for the Gloeomargarita and the Thermosynechococcus/S. calcipolaris clades. In cases where no amplification product was obtained, nested or semi-nested amplifications from amplicons obtained with general cyanobacterial primers CYA106F and CYA-1380R were additionally tested. In general, nested or semi-nested amplification attempts failed, suggesting the absence of the targeted sequences from the corresponding samples. 16S rRNA gene libraries were constructed for all positive amplifications using 


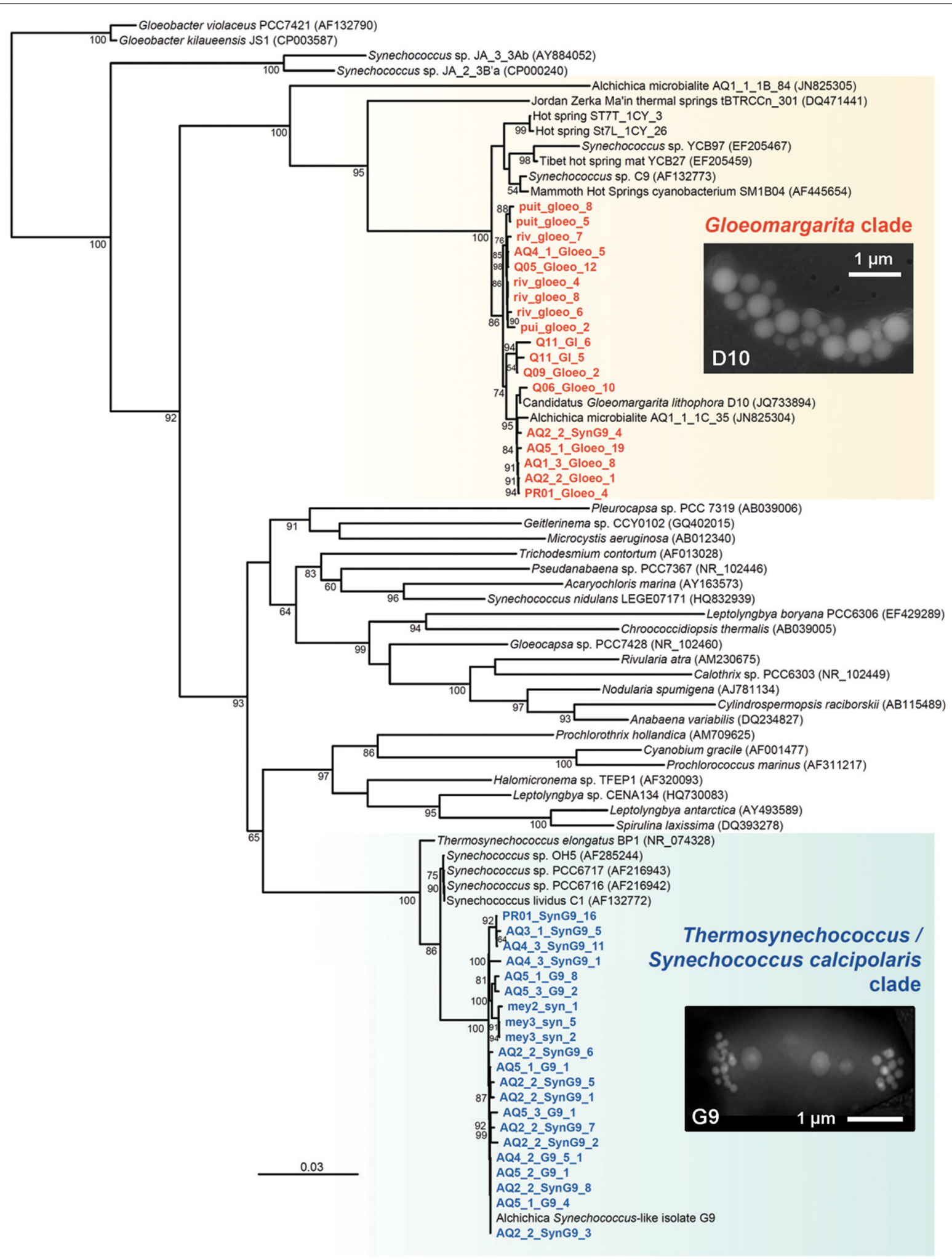

FIGURE 1 | Phylogenetic tree showing the diversity and the position of two lineages of cyanobacteria producing intracellular carbonate inclusions. Scanning microscopy photographs of inclusion-bearing cells belonging to representative strains of the Gloeomargarita and the Thermosynechococcus/S. calcipolaris clades are shown as insets. The tree was reconstructed using 1025 conserved positions. The environmental sequences obtained in this work are shown in color. Accession numbers of sequences retrieved from GenBank are given between brackets. Only bootstrap values higher than $50 \%$ are given at nodes. The scale bar represents the number of substitutions per a unit branch length. 
the TopoTA cloning kit (Invitrogen, Carlsbad, CA, USA) according to the manufacturer's instructions. A total of 35 libraries were constructed for Themosynechococcus/S. calcipolaris-like amplicons from different samples and 30 libraries for the Gloeomargarita clade. Clone inserts were PCR-amplified using flanking vector primers, and inserts of expected size were partially sequenced (Beckman Coulter Genomics, Takeley, UK) with reverse primer $1227 \mathrm{R}$ or $1231 \mathrm{R}$, yielding sequences of ca. $800 \mathrm{bp}$. A total of 201 cyanobacterial clones were sequenced (33 for Themosynechococcus/S. calcipolaris and 168 for Gloeomargarita clades). All the sequences obtained were highly similar (>97\% identity) but several clones that appeared slightly different were fully sequenced by using forward primers. Complete sequences were assembled using Code Aligner (CodonCode Corporation; www.codoncode.com) prior to phylogenetic analyses. Sequences were deposited in GenBank with accession numbers KJ636536KJ636761.

\section{PHYLOGENETIC ANALYSES}

Environmental 16S rRNA gene sequences retrieved from our samples were compared with sequences in the GenBank database (http://www.ncbi.nlm.nih.gov/) by BLAST (Altschul et al., 1997). We retrieved the closest sequences found in the database and included them in an alignment containing also sequences from the closest cultivated members and some representative sequences of major cyanobacterial taxa. Sequences were aligned using MUSCLE (Edgar, 2004). Ambiguously aligned positions and gaps were eliminated using Gblocks (Castresana, 2000). The resulting sequence alignments were used as input to build phylogenetic trees by approximate maximum likelihood using Fasttree (Price et al., 2010) with a General Time Reversible (GTR) model of sequence evolution, and taking among-site rate variation into account by using a four-category discrete approximation of a $\Gamma$ distribution. ML bootstrap proportions were inferred using 1000 replicates. Trees were visualized with FigTree (http://tree.bio.ed. ac.uk/software/figtree/).

\section{SCANNING ELECTRON MICROSCOPY AND ENERGY DISPERSIVE X-RAY SPECTROMETRY}

Samples of freshly collected aquaria biofilms and microbial mat samples were briefly rinsed in abundant distilled water to avoid the formation of extracellular precipitates upon drying, as previously described (Couradeau et al., 2012, 2013). Then, small sample fragments were deposited onto on formvar-coated transmission electron microscopy (TEM) cupper microscopy grids and let dry. Scanning electron microscopy (SEM) analyses were performed using a Zeiss ultra 55 SEM equipped with a field emission gun. Images were collected in backscattered electron (BSE) mode with a Zeiss Ultra 55 FEG-SEM operating at $10 \mathrm{kV}$ with a $30 \mu \mathrm{m}$ aperture and a working distance of $7.5 \mathrm{~mm}$ using the Angle selective Backscattered (AsB) detector. This mode of imaging provides a contrast which is sensitive to the average atomic number, hence allowing detecting intracellular carbonate inclusions. Elemental compositions of the observed mineral precipitates were directly determined by energy dispersive $\mathrm{x}$-ray spectrometry (EDXS) using an EDS QUANTAX detector and the software ESPRIT (Bruker Corporation, Germany) as previously achieved by Couradeau et al. (2013).

\section{RESULTS AND DISCUSSION DETECTION OF GLOEOMARGARITA AND THERMOSYNECHOCOCCUS/S. CALCIPOLARIS CLADES IN ENVIRONMENTAL SAMPLES}

The first step to detect the environmental presence of the two groups of cyanobacteria to which Candidatus G. lithophora and S. calcipolaris G9 belong involved the design specific primers to amplify their respective $16 \mathrm{~S}$ rRNA genes. These primers targeted a relatively broad diversity of cultured and uncultured cyanobacteria forming a monophyletic cluster with each of them (colored areas in Figure 1), and were validated with control DNA from available cultured species (see Materials and Methods). In the case of Gloeomargarita, our primers were designed to capture the diversity within a large cluster including the only cultivated member of the group, Candidatus $\mathrm{G}$. lithophora, as well as several close environmental sequences, mainly retrieved from thermophilic mats or hot springs, but also from more distant cyanobacteria, including the early-branching operational taxonomic unit (OTU) AQ1-1-1B-84 from Lake Alchichica microbialites (Couradeau et al., 2011) and a sequence from a filamentous thermophilic cyanobacterium (tBTRCCn 301) retrieved from a thermal spring in Jordan (Figure 1). In the case of Ca. S. calcipolaris G9, the clade seemed less diverse, with relatively few related sequences in GenBank. Indeed, the closest sequences to $\mathrm{Ca}$. S. calcipolaris G9 corresponded to those of cultured species, including four highly related Synechococcus species (S. lividus and Synechococcus sp. PCC6716, PCC6717, and OH5) and Thermosynechococcus elongatus, all of which are thermophilic (Dyer and Gafford, 1961; Miller and Castenholz, 2000; Nakamura et al., 2002) (Figure 1). Therefore, in the following, we will refer to this clade indistinctly as the Thermosynechococcus clade or the Synechococcus calcipolaris-like clade.

Because both G. lithophora and S. calcipolaris G9 were enriched from carbonate microbialites of the alkaline Lake Alchichica and because their closest relatives in GenBank had been most often identified in thermophilic microbial mats, we searched to identify these clades in a broad collection of samples collected worldwide that included thermophilic settings compatible with photosynthesis $\left(40-70^{\circ} \mathrm{C}\right)$ and carbonate-rich environments, such as microbialites and karstic areas (Table 1). In particular, we explored the presence of the two clades in different microbialite samples from Lake Alchichica collected at different locations along the shore of the lake, time, and depths (from 0 to $15 \mathrm{~m}$ depth). We also analyzed microbialite samples from neighboring lakes, including Quechulac, La Preciosa, and Atexcac. We tried to amplify the 16S rRNA genes from the two clades in a total of 62 samples (Table 1). From these, amplicons of the expected size were obtained in a total of 20 samples for the Gloeomargarita clade, whereas only 15 were obtained for the $S$. calcipolaris-like clade. All of them were cloned and, in the vast majority of cases, the corresponding clone sequences belonged to the targeted groups (see below), showing a high specificity of the designed primers. Only in a few instances, always after nested or semi-nested PCR, were other cyanobacterial sequences retrieved.

The Gloeomargarita group was detected in microbialites from Alchichica, Quechulac, La Preciosa, and Atexcac lakes (Table 1). However, Gloeomargarita identification consistently failed in deep microbialites, being undetected in Alchichica samples from 5, 
10, and $15 \mathrm{~m}$ as well as in microbialites collected at $15 \mathrm{~m}$ depth and kept afterwards in laboratory aquaria. By contrast, Gloeomargarita 16S rRNA genes were amplified from all Alchichica microbialites collected down to $1 \mathrm{~m}$ depth, including those maintained in aquaria. They were also amplified from Atexcac, La Preciosa, and Quechulac, but not from all the samples tested (Table 1). Heterogeneous amplification from different samples coming from the same lake was a much stronger trend for the $S$. calcipolaris-like group. Indeed, its detection in microbialites from Alchichica and surrounding lakes was patchy. This may simply reflect the highly heterogeneous nature of the microbialite environment, which may result in local differences in the distribution of different microbial taxa. However, given that this should also affect the amplification of Gloeomargarita $16 \mathrm{~S}$ rDNAs, this patchier detection suggests that, although similarly largely distributed in these lacustrine microbialites, the Synechococcus-like G9 clade is less abundant as compared to Gloeomargarita.

In addition to the microbialites in the Alchichica area, the Gloeomargarita clade was also detected in microbial mat samples collected from karstic environments in the Southwest of France (Parc Naturel Régional des Grands Causses and surrounding areas) as well as in a hypersaline microbial mat of the Salada de Chiprana, Spain (Table 1). Interestingly, carbonate precipitation occurs within Chiprana hypersaline mats (Vidondo et al., 1993), most likely due to a combination of photosynthetic and sulfatereducing activities (Ludwig et al., 2005). Similarly, the S. calcipolaris-like group was detected in mats growing on carbonate rocks from karstic areas in Southern France but also in a microbial mat from El Tatio, a vast hydrothermal field located at high altitude (4300 m) in the Chilean Andes (Table 1). Notably, neither group was detected in plankton samples from karstic systems (encompassing a Mexican cenote and a sample from Southern France) or from the French crater lake Pavin.

Although more prevalent in crater lake microbialites, the identification of the Gloeomargarita and the S. calcipolaris-like groups in samples coming from other, very distant locations, indicates that the distribution of these lineages is cosmopolitan. Ecologically, the two cyanobacterial groups seem to thrive preferentially in thermophilic mats (Dyer and Gafford, 1961; Miller and Castenholz, 2000; Nakamura et al., 2002; Couradeau et al., 2012) or in carbonate rocks, either lake microbialites or carbonates from karstic areas. Interestingly, other deep-branching cyanobacterial groups, such as the Gloeobacter lineage, are also associated with rock environments (Mares et al., 2013).

\section{WITHIN-GROUP DIVERSITY OF GLOEOMARGARITA AND THERMOSYNECHOCOCCUS/S. CALCIPOLARIS LINEAGES}

Surprisingly, even if our specific primers were designed to capture a wide phylogenetic diversity, and even if the sequences obtained came from very different locations, all the $16 \mathrm{~S}$ rRNA gene sequences that we obtained were all very similar sharing, within each clade, more than 97\% identity, the cut-off usually established to define prokaryotic OTUs (Figure 1 and Figure S1). Despite this high similarity, there were some differences possibly reflecting strain variation. Some of this strain variation might reflect local adaptations influenced by geographic and/or physico-chemical differences, both types of factors being very difficult to disentangle. This might perhaps be the case of S. calcipolaris G9-like sequences from Atexcac or Meyrueis/El Tatio or of some Gloeomargarita-like sequences from Chiprana, Alchichica or Quechulac (Figure S1). To really check for strain differentiation, studies using additional, more variable, phylogenetic markers (e.g., multi-locus sequence typing) would be needed.

In summary, the diversity of Gloeomargarita and the S. calcipolaris G9-like group was extremely limited within samples and also across continents and ecosystems. Their low intra-group diversity and the fact that these cyanobacteria (especially the Thermosynechococcus group) did not appear dominant in many of the analyzed samples suggest that they are specialists. These two cyanobacterial lineages provide good examples of the tenet "everything is everywhere, but the environment selects" (BaasBecking, 1934; Martiny et al., 2006), since they encompass a few cosmopolitan OTUs subjected to strong environmental selection.

\section{CALCIFICATION POTENTIAL IN THE ENVIRONMENT}

Among prokaryotes, it is well known that similar 16S rRNA sequences do not necessarily imply similar phenotypic properties. Therefore, even if we detected 16S rRNA gene sequences very closely related to the two Alchichica intracellularly calcifying cyanobacteria G. lithophora and S. calcipolaris G9, their capability to form intracellular carbonates remained to be shown. Therefore, we carried out scanning electron microscope (SEM) observations on fresh environmental samples where they might be relatively abundant to look for the presence of intracellularly calcifying cyanobacterial cells.

The Gloeomargarita clade is more diverse, but so far only G. lithophora has been shown to possess intracellular carbonate precipitates both in enrichment cultures and in the biofilm it was originally enriched from Couradeau et al. (2012). Sequences affiliating to G. lithophora were also present in Alchichica microbialites, but their abundance in such a complex and diversity-rich environment seemed too low for SEM detection to be feasible (Couradeau et al., 2011). By contrast, confirming original observations, our analysis of wall-biofilm samples from two different aquaria (AQ1 and AQ2) showed a high density of G. lithophora cells containing a huge amount of intracellular $\mathrm{Ca}, \mathrm{Mg}, \mathrm{Sr}$, and $\mathrm{Ba}$-enriched carbonate precipitates (Figures $2 \mathrm{~A}-\mathrm{C}$ ), as confirmed by energy dispersive $\mathrm{x}$-ray spectrometry (EDX) analyses (Couradeau et al., 2012, and data not shown). This remarkable abundance suggests that G. lithophora is particularly fit to this type of biofilm environment and/or that is among the first biofilm-forming organisms on solid substrates (the glass wall in this case). G. lithophora not only forms carbonate inclusions in this semi-natural environment, but seems to have a much higher precipitate content than cultures in BG11 medium (Benzerara et al., in press).

In addition, a recent study of cyanobacterial diversity showed a remarkable relative abundance of sequences (up to 12\%) belonging to the Gloeomargarita clade in a calcifying microbial mat from a hot spring at Meskoutine, Algeria (site St7, 55-70 ${ }^{\circ} \mathrm{C}$ ) (Amarouche-Yala et al., under review). We therefore looked for the presence of cells containing intracellular carbonates using SEM. As can be seen in Figures 2D-H, we identified a number of cells compatible in size and shape with Gloeomargarita sp. and 

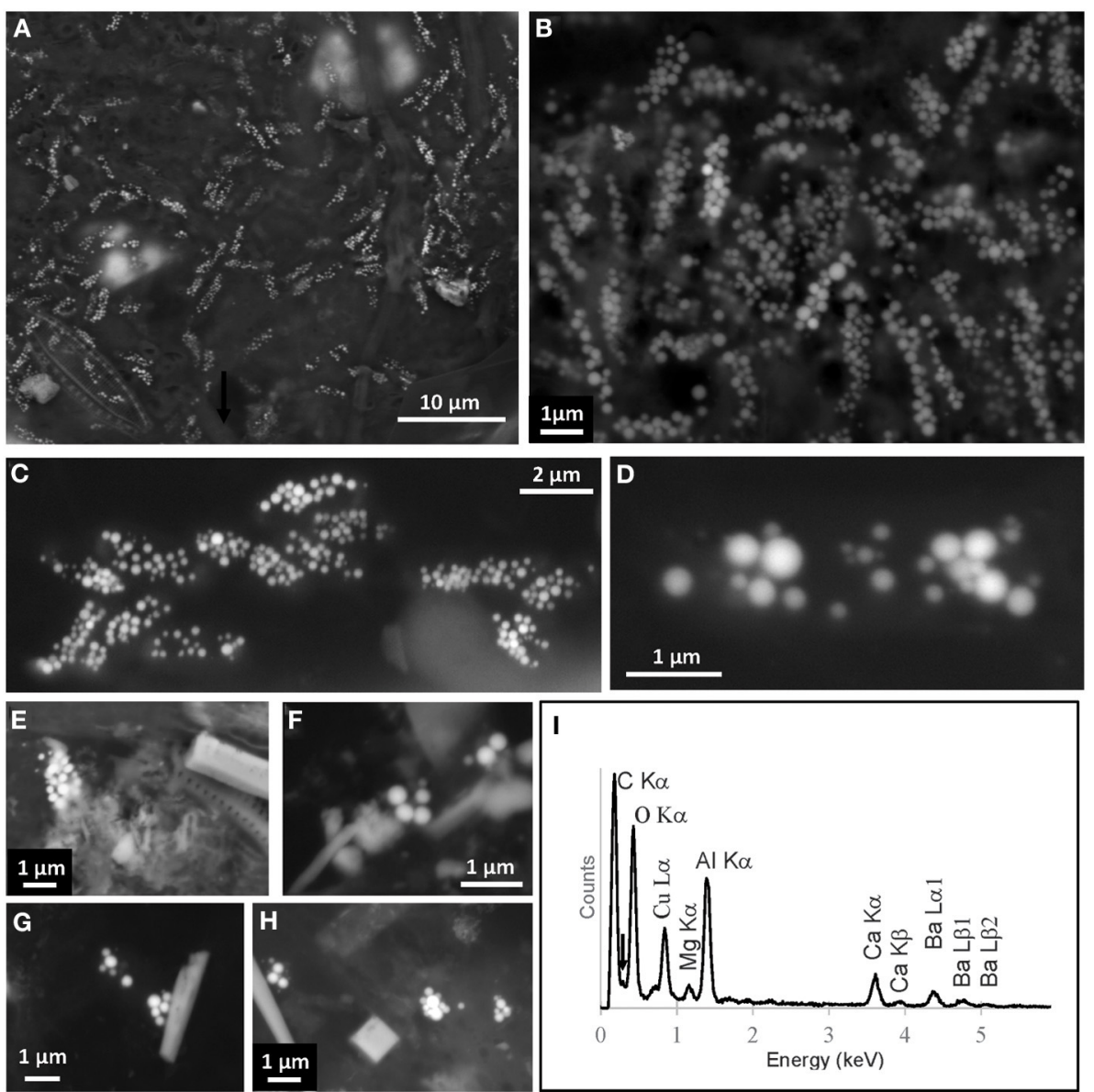

FIGURE 2 | Scanning electron microscopy images of cyanobacteria with intracellular carbonate inclusions in environmental samples. $(\mathbf{A}, \mathbf{B})$ Images of Gloeomargarita-like cells growing in the biofilm of aquarium AQ1 where G. lithophora was isolated from. (C)

Gloeomargarita-like cells in a biofilm sample from aquarium AQ2. (D-H) Individual Gloeomargarita-like cells in natural thermophilic mat samples (Algerian hot spring St7, Meskoutine; Amarouche-Yala et al., under review). Cell boundaries are difficult to observe due to the absence of fixation and staining to prevent carbonate dissolution. (I) Energy dispersive $x$-ray spectrometry (EDXS) analysis on intracellular inclusions of the cell shown in (D) from the hot spring St7 microbial mat. C, N (arrow), O, Ca, and $\mathrm{Ba}$ can be detected from the inclusions in the cells. $\mathrm{Al}$ and $\mathrm{Cu}$ emission lines are due to the TEM copper grid and the aluminum sample holder. containing intracellular biominerals. EDX analyses on these precipitates showed that they contained carbon, calcium and barium, and lacked phosphorous or sulfur (Figure 2I). This suggests that these inclusions are carbonates of calcium and barium. Barium occurrence in the relatively divergent St7 Gloeomargarita-like cells together with previous observations on G. lithophora (Couradeau et al., 2012) strongly argue for the general capacity of this clade to concentrate barium intracellularly. Our observations suggest that members of the apical Gloeomargarita clade, encompassing G. lithophora and the St7 phylotypes (Figure 1) do form intracellular carbonates in their natural environment. However, whether more basal OTUs in the clade can produce intracellular carbonate inclusions or not remains to be determined.

In the case of the Thermosynechococcus/S. calcipolaris G9 group, all the cultured species examined, including the more basal T. elongatus, do form intracellular calcium carbonates in culture (Benzerara et al., in press). However, we have never been able to observe individual cells with their characteristic polar carbonates in environmental samples. Given the universal ability of members of this clade to precipitate carbonate inclusions intracellularly in culture media, and given that Gloeomargarita cells form large amounts of carbonate inclusions in the natural environments where they are found, it is likely that $S$. calcipolaris G9-like cells do also produce intracellular precipitates in natural environments. The failure to identify them in natural samples may be related to their low relative abundance in the environments examined. Whether members of this cosmopolitan group are more abundant in other, yet-to-explore ecosystems remains to be determined.

In summary, our study shows that two relatively basal lineages of cyanobacteria producing intracellular carbonates by two different mechanisms are cosmopolitan and exhibit preference for moderately thermophilic microbial mats and microbialites or other, karstic carbonate-rocks. Some of these cyanobacteria, at least members of the Gloeomargarita clade, can be relatively abundant locally. Therefore, their contribution to carbonate precipitation in those ecosystems on the long run may be far from 
negligible. Furthermore, since these lineages are relatively earlybranching (Criscuolo and Gribaldo, 2011; Couradeau et al., 2012; Shih et al., 2013), if their ability to produce intracellular carbonates was ancestral, they may have been important contributors to carbonate production in the geological record (Riding, 2000), especially because thermophilic mats and microbialites were likely more prevalent in the past. The idea that intracellular calcification may have been more important in the past is further reinforced by the recent discovery that this phenomenon is much more widespread than previously thought among cyanobacteria (Benzerara et al., in press). Altogether, these observations lend credit to the hypothesis that extracellular fossilization in cyanobacteria appeared relatively late, perhaps linked to the development of carbon concentrating mechanisms by cyanobacteria, major environmental changes at the surface of the Earth and/or the appearance of conspicuous EPS layers, and might help to explain why cyanobacterial microfossils are not detectable in very old fossil stromatolites (the so-called "Precambrian enigma") (Couradeau et al., 2012; Riding, 2012).

\section{ACKNOWLEDGMENTS}

We are grateful to Ana Isabel López-Archilla, Ludwig Jardillier and Emmanuelle Gérard for providing some of the samples tested in this study (Chiprana, Les Causses, Mayotte), and to Samia Amarouche-Yala for the thermophilic mat sample on which SEM analysis was performed. The research leading to these results has received funding from the European Research Council under the European Community's Seventh Framework Program (FP7/2007-2013 Grant Agreement no. 307110 - ERC CALCYAN). The Scanning Electron Microscope (SEM) facility of the Institut de Minéralogie et de Physique des Milieux Condensés has been purchased owing to the Région Ile de France grant SESAME $2006 N^{\circ}$ I-07-593/R, INSU-CNRS, INP-CNRS, University Pierre et Marie Curie - Paris 6.

\section{SUPPLEMENTARY MATERIAL}

The Supplementary Material for this article can be found online at: http://www.frontiersin.org/journal/10.3389/fmicb. 2014.00331/abstract

\section{REFERENCES}

Altschul, S. F., Madden, T. L., Schaffer, A. A., Zhang, J., Zhang, Z., Miller, W., et al. (1997). Gapped BLAST and PSI-BLAST: a new generation of protein database search programs. Nucleic Acids Res. 25, 3389-3402. doi: 10.1093/nar/25. 17.3389

Arp, G., Reimer, A., and Reitner, J. (1999). Calcification in cyanobacterial biofilms of alkaline salt lakes. Eur. J. Phycol. 34, 393-403. doi: 10.1080/09670269910001736452

Arp, G., Reimer, A., and Reitner, J. (2001). Photosynthesis-induced biofilm calcification and calcium concentrations in Phanerozoic oceans. Science 292, 1701-1704. doi: 10.1126/science.1057204

Baas-Becking, L. G. M. (1934). Geobiologie of Inleiding tot de Milieukunde. The Hague: W. P. Van Stockum and Zoon.

Bauerlein, E. (2003). Biomineralization of unicellular organisms: an unusual membrane biochemistry for the production of inorganic nano- and microstructures. Angew. Chem. Int. Ed. Engl. 42, 614-641. doi: 10.1002/anie.200390176

Benzerara, K., Menguy, N., Lopez-Garcia, P., Yoon, T. H., Kazmierczak, J., Tyliszczak, T., et al. (2006). Nanoscale detection of organic signatures in carbonate microbialites. Proc. Natl. Acad. Sci. U.S.A. 103, 9440-9445. doi: 10.1073/pnas.0603255103
Benzerara, K., Skouri-Panet, F., Li, J., Férard, C., Gugger, M., Laurent, T., et al. (in press). Intracellular Ca-carbonate biomineralization is widespread in cyanobacteria. Proc. Natl. Acad. Sci. U.S.A.

Bundeleva, I. A., Shirokova, L. S., Benezeth, P., Pokrovsky, O. S., Kompantseva, E. I., and Balor, S. (2012). Calcium carbonate precipitation by anoxygenic phototrophic bacteria. Chem. Geol. 291, 116-131. doi: 10.1016/j.chemgeo.2011.10.003

Castresana, J. (2000). Selection of conserved blocks from multiple alignments for their use in phylogenetic analysis. Mol. Biol. Evol. 17, 540-552. doi: 10.1093/oxfordjournals.molbev.a026334

Couradeau, E., Benzerara, K., Gérard, E., Estève, I., Moreira, D., Tavera, R., et al. (2013). In situ microscale cyanobacterial calcification in modern microbialites. Biogeosciences 10, 5255-5266. doi: 10.5194/bg-10-5255-2013

Couradeau, E., Benzerara, K., Gerard, E., Moreira, D., Bernard, S., Brown, G. E. Jr., et al. (2012). An early-branching microbialite cyanobacterium forms intracellular carbonates. Science 336, 459-462. doi: 10.1126/science.1216171

Couradeau, E., Benzerara, K., Moreira, D., Gerard, E., Kazmierczak, J., Tavera, R., et al. (2011). Prokaryotic and eukaryotic community structure in field and cultured microbialites from the alkaline Lake Alchichica (Mexico). PLoS ONE 6:e28767. doi: 10.1371/journal.pone.0028767

Criscuolo, A., and Gribaldo, S. (2011). Large-scale phylogenomic analyses indicate a deep origin of primary plastids within cyanobacteria. Mol. Biol. Evol. 28, 3019-3032. doi: 10.1093/molbev/msr108

Dupraz, C., Reid, R. P., Braissant, O., Decho, A. W., Norman, R. S., and Visscher, P. T. (2009). Processes of carbonate precipitation in modern microbial mats. Earth Sci. Rev. 96, 141-162. doi: 10.1016/j.earscirev.2008.10.005

Dupraz, C., and Visscher, P. T. (2005). Microbial lithification in marine stromatolites and hypersaline mats. Trends Microbiol. 13, 429-438. doi: 10.1016/j.tim.2005.07.008

Dyer, D. L., and Gafford, R. D. (1961). Some characteristics of a thermophilic bluegreen alga. Science 134, 616-617. doi: 10.1126/science.134.3479.616

Edgar, R. C. (2004). MUSCLE: multiple sequence alignment with high accuracy and high throughput. Nucleic Acids Res. 32, 1792-1797. doi: 10.1093/nar/gkh340

Gallagher, K. L., Kading, T. J., Braissant, O., Dupraz, C., and Visscher, P. T. (2012). Inside the alkalinity engine: the role of electron donors in the organomineralization potential of sulfate-reducing bacteria. Geobiology 10, 518-530. doi: 10.1111/j.1472-4669.2012.00342.x

Gerard, E., Menez, B., Couradeau, E., Moreira, D., Benzerara, K., Tavera, R., et al. (2013). Specific carbonate-microbe interactions in the modern microbialites of Lake Alchichica (Mexico). ISME J. 7, 1997-2009. doi: 10.1038/ismej.2013.81

Gerdes, G., Dunajtschikpiewak, K., Riege, H., Taher, A. G., Krumbein, W. E., and Reineck, H. E. (1994). Structural diversity of biogenic carbonate particles in microbial mats. Sedimentology 41, 1273-1294. doi: 10.1111/j.13653091.1994.tb01453.x

Gomez-Garcia, M. R., Fazeli, F., Grote, A., Grossman, A. R., and Bhaya, D. (2013). Role of polyphosphate in thermophilic Synechococcus sp. from microbial mats. J. Bacteriol. 195, 3309-3319. doi: 10.1128/JB.00207-13

Greene, S. E., and Komeili, A. (2012). Biogenesis and subcellular organization of the magnetosome organelles of magnetotactic bacteria. Curr. Opin. Cell Biol. 24, 490-495. doi: 10.1016/j.ceb.2012.05.008

Hammes, F., Boon, N., De Villiers, J., Verstraete, W., and Siciliano, S. D. (2003). Strain-specific ureolytic microbial calcium carbonate precipitation. Appl. Environ. Microbiol. 69, 4901-4909. doi: 10.1128/AEM.69.8.4901-4909.2003

Head, I. M., Gray, N. D., Clarke, K. J., Pickup, R. W., and Jones, J. G. (1996). The phylogenetic position and ultrastructure of the uncultured bacterium Achromatium oxaliferum. Microbiology 142, 2341-2354. doi: 10.1099/00221287142-9-2341

Lefevre, C. T., and Bazylinski, D. A. (2013). Ecology, diversity, and evolution of magnetotactic bacteria. Microbiol. Mol. Biol. Rev. 77, 497-526. doi: 10.1128/MMBR.00021-13

Lins, U., and Farina, M. (1999). Phosphorus-rich granules in uncultured magnetotactic bacteria. FEMS Microbiol. Lett. 172, 23-28. doi: 10.1111/j.15746968.1999.tb13444.x

Ludwig, R., Al-Horani, F. A., De Beer, D., and Jonkers, H. M. (2005). Photosynthesis-controlled calcification in a hypersaline microbial mat. Limnol. Oceanogr. 50, 1836-1843. doi: 10.4319/lo.2005.50.6.1836

Mares, J., Hrouzek, P., Kana, R., Ventura, S., Strunecky, O., and Komarek, J. (2013). The primitive thylakoid-less cyanobacterium Gloeobacter is a common rockdwelling organism. PLoS ONE 8:e66323. doi: 10.1371/journal.pone.0066323 
Martiny, J. B., Bohannan, B. J., Brown, J. H., Colwell, R. K., Fuhrman, J. A., Green, J. L., et al. (2006). Microbial biogeography: putting microorganisms on the map. Nat. Rev. Microbiol. 4, 102-112. doi: 10.1038/nrmicro1341

Michaelis, W., Seifert, R., Nauhaus, K., Treude, T., Thiel, V., Blumenberg, M., et al. (2002). Microbial reefs in the Black Sea fueled by anaerobic oxidation of methane. Science 297, 1013-1015. doi: 10.1126/science. 1072502

Miller, S. R., and Castenholz, R. W. (2000). Evolution of thermotolerance in hot spring cyanobacteria of the genus Synechococcus. Appl. Environ. Microbiol. 66, 4222-4229. doi: 10.1128/AEM.66.10.4222-4229.2000

Nakamura, Y., Kaneko, T., Sato, S., Ikeuchi, M., Katoh, H., Sasamoto, S., et al. (2002). Complete genome structure of the thermophilic cyanobacterium Thermosynechococcus elongatus BP-1. DNA Res. 9, 123-130. doi: 10.1093/dnares/9.4.123

Newman, D. K., and Banfield, J. F. (2002). Geomicrobiology: how molecular-scale interactions underpin biogeochemical systems. Science 296, 1071-1077. doi: $10.1126 /$ science. 1010716

Obst, M., Dynes, J. J., Lawrence, J. R., Swerhone, G. D. W., Benzerara, K., Karunakaran, C., et al. (2009). Precipitation of amorphous CaCO3 (aragonite-like) by cyanobacteria: a STXM study of the influence of EPS on the nucleation process. Geochim. Cosmochim. Acta 73, 4180-4198. doi: 10.1016/j.gca.2009.04.013

Overmann, J., and Garcia-Pichel, F. (2000). "The phototrophic way of life," in The Prokaryotes: An Evolving Electronic Resource for the Microbiological Community, 3rd Edn., ed M. Dworkin (New York, NY: Springer-Verlag). Available online at: http://link.springer-ny.com/link/service/books/10125/

Paerl, H. W., Steppe, T. F., and Reid, R. P. (2001). Bacterially mediated precipitation in marine stromatolites. Environ. Microbiol. 3, 123-130. doi: 10.1046/j.14622920.2001.00168.x

Planavsky, N., Reid, R. P., Lyons, T. W., Myshrall, K. L., and Visscher, P. T. (2009). Formation and diagenesis of modern marine calcified cyanobacteria. Geobiology 7, 566-576. doi: 10.1111/j.1472-4669.2009.00216.x

Price, M. N., Dehal, P. S., and Arkin, A. P. (2010). FastTree 2-approximately maximum-likelihood trees for large alignments. PLOS ONE 5:e9490. doi: 10.1371/journal.pone.0009490

Reid, R. P., Visscher, P. T., Decho, A. W., Stolz, J. F., Bebout, B. M., Dupraz, C., et al. (2000). The role of microbes in accretion, lamination and early lithification of modern marine stromatolites. Nature 406, 989-992. doi: 10.1038/35023158

Riding, R. (2000). Microbial carbonates: the geological record of calcified bacterialalgal mats and biofilms. Sedimentology 47, 179-214. doi: 10.1046/j.13653091.2000.00003.x

Riding, R. (2006). Cyanobacterial calcification, carbon dioxide concentrating mechanisms, and Proterozoic-Cambrian changes in atmospheric composition. Geobiology 4, 299-316. doi: 10.1111/j.1472-4669.2006.00087.x

Riding, R. (2012). Geochemistry. A hard life for cyanobacteria. Science 336, 427-428. doi: 10.1126/science. 1221055

Rivadeneyra, M. A., Delgado, G., Soriano, M., Ramos-Cormenzana, A., and Delgado, R. (1999). Biomineralization of carbonates by Marinococcus albus and Marinococcus halophilus isolated from the Salar de Atacama (Chile). Curr. Microbiol. 39, 53-57. doi: 10.1007/PL00006827
Robertson, B. R., Tezuka, N., and Watanabe, M. M. (2001). Phylogenetic analyses of Synechococcus strains (cyanobacteria) using sequences of 16S rDNA and part of the phycocyanin operon reveal multiple evolutionary lines and reflect phycobilin content. Int. J. Syst. Evol. Microbiol. 51, 861-871. doi: 10.1099/0020771351-3-861

Robertson, L. A., and Kuenen, J. G. (2006). “The colorless sulfur bacteria," in The Prokaryotes, 3rd Edn., eds M. Dworkin, S. Falkow, E. Rosenberg, K. H. Schleifer, and E. Stackebrandt (New York, NY: Springer), 985-1011.

Rodriguez-Navarro, C., Rodriguez-Gallego, M., Ben Chekroun, K., and GonzalezMunoz, M. T. (2003). Conservation of ornamental stone by Myxococcus xanthus-induced carbonate biomineralization. Appl. Environ. Microbiol. 69, 2182-2193. doi: 10.1128/AEM.69.4.2182-2193.2003

Seufferheld, M., Vieira, M. C. F., Ruiz, F. A., Rodrigues, C. O., Moreno, S. N. J., and Docampo, R. (2003). Identification of organelles in bacteria similar to acidocalcisomes of unicellular eukaryotes. J. Biol. Chem. 278, 29971-29978. doi: 10.1074/jbc.M304548200

Shih, P. M., Wu, D., Latifi, A., Axen, S. D., Fewer, D. P., Talla, E., et al. (2013). Improving the coverage of the cyanobacterial phylum using diversitydriven genome sequencing. Proc. Natl. Acad. Sci. U.S.A. 110, 1053-1058. doi: $10.1073 /$ pnas. 1217107110

Thompson, J. B., Schultze-Lam, S., Beveridge, T. J., and Des Marais, D. J. (1997). Whiting events: biogenic origin due to the photosynthetic activity of cyanobacterial picoplankton. Limnol. Oceanogr. 42, 133-141. doi: 10.4319/lo.1997.42.1.0133

Vidondo, B., Martinez, B., Montes, C., and Guerrero, M. C. (1993). Physicochemica characteristics of a permanent Spanish hypersaline lake - La Salada de Chiprana (NE Spain). Hydrobiologia 267, 113-125. doi: 10.1007/BF00018794

Visscher, P. T., Reid, P. R., and Bebout, B. M. (2000). Microscale observations of sulfate reduction: correlation of microbial activity with lithified micritic laminae in modern marine stromatolites. Geology 28, 919-922. doi: 10.1130/00917613(2000)282.0.CO;2

Conflict of Interest Statement: The authors declare that the research was conducted in the absence of any commercial or financial relationships that could be construed as a potential conflict of interest.

Received: 23 March 2014; accepted: 16 June 2014; published online: 08 July 2014. Citation: Ragon M, Benzerara K, Moreira D, Tavera R and López-García P (2014) $16 S$ rDNA-based analysis reveals cosmopolitan occurrence but limited diversity of two cyanobacterial lineages with contrasted patterns of intracellular carbonate mineralization. Front. Microbiol. 5:331. doi: 10.3389/fmicb.2014.00331

This article was submitted to Aquatic Microbiology, a section of the journal Frontiers in Microbiology.

Copyright (c) 2014 Ragon, Benzerara, Moreira, Tavera and López-García. This is an open-access article distributed under the terms of the Creative Commons Attribution License (CC BY). The use, distribution or reproduction in other forums is permitted, provided the original author(s) or licensor are credited and that the original publication in this journal is cited, in accordance with accepted academic practice. No use, distribution or reproduction is permitted which does not comply with these terms. 